\title{
DO GREEN MARKETING AND GREEN BRAND AWARENESS INFLUENCE CUSTOMER SATISFACTION? AN EMPIRICAL STUDY
}

\author{
Alum Kusumah ${ }^{1 *}$, Cheng-Wen Lee ${ }^{2}$ \\ ${ }^{1}$ Faculty of Economics and Business, Universitas Muhammadiyah Riau, Pekanbaru, \\ Indonesia \\ 2International Business and Trade Department, College of Business, Chung Yuan Christian \\ University, Taoyuan City, Taiwan \\ alumkusumah@gmail.com \\ chengwen@cycu.edu.tw
}

\begin{abstract}
The importance of this study in bridging the gap between existing research literature works by analysing the influence of green marketing and awareness of the green brand on customer satisfaction of mineral water products. The analysis adopted a quantitative and analytical approach by administering structured questionnaires. The questionnaire developed based on the objectives of the research and the analysis of the relevant literature on green marketing, green brand awareness, and customer satisfaction. The results revealed green marketing had no influence on customer satisfaction in the case of the Pristine $8+$ bottled mineral water customers. However, it was found that green brand awareness has a positive influence on customer satisfaction. Green marketing and green brand awareness simultaneously have a positive influence on customer satisfaction of the Pristine 8 + bottled mineral water brand. This study expands the scientific literature by providing empirical evidence on green marketing, green brand awareness on customer satisfaction that also can use as a consideration that might help companies to make decisions that will allow them to surpass their competitors through green marketing and green brand awareness, and to meet their customer satisfaction.
\end{abstract}

Keywords: Green marketing, Green brand awareness, Customer Satisfaction, empirical study, Mineral water product.

JEL classification: M31, M39

\section{Introduction}

The modern era is committed to environmentally sustainable and green marketing needs are being recognized throughout the world. Environmental and health concerns and awareness have changed people and business perceptions and behaviors. Consumers worldwide are aware of the detrimental effects of non-eco-friendly products on the environment. Consumers' concern for the environment has increased substantially, and demand for a green product has emerged. 'Green' has been used to represent certain branding strategies, such as healthy, energy-efficient, and environmentally-friendly (Parker, Segev, and Pinto, 2010). Many businesses around the world implement a green marketing strategy for a variety of reasons, such as protecting themselves against relevant regulations, responding to green consumer demands and competing with other green products, or altering their business philosophy (Grant, 2008).

Water is one of the human's most essential elements since humans could never live without water. The need for clean water will always increase from time to time, as the number of

* Corresponding author: Alum Kusumah 
people rises. Mineral water is present as an alternative for consuming healthy drinking water to meet their needs. Technology development and population growth are now widening market opportunities and prompting mineral water companies to continue to innovate and broaden their distribution networks to compete with other mineral water companies, leading to increasingly fierce competition between mineral water companies. This indicates the business must consistently strive to improve the product quality, pay close attention to pricing, and be innovative in the creation and development of its products.

The objective of the study is to examine the influence of green marketing and green brand awareness on customer satisfaction of mineral water products under the Pristine $8+$ brand in Riau Province, Indonesia. In terms of developing new and improved products and services with environmental inputs, the study has its significance for the companies to gain customer satisfaction and maintain a competitive advantage over non-environmental business concerns. Besides, companies consider green marketing and green branding as advantages that can be used to achieve their goals and have a moral obligation to be more socially responsible for delivering green products. This study expands the scientific literature by providing empirical evidence on green marketing, green brand awareness on customer satisfaction, that can also be used as a consideration that could help companies make the decisions that will allow them to surpass their competitors through green marketing and green brand awareness, and meet their customer satisfaction.

\section{Literature Review}

\subsection{Green marketing}

Green marketing is a concept and strategy to protect the environment. A market segment has arisen, i.e. the green market due to the growing concern for environmental protection (Yan \& Yazdanifard, 2014). The term green marketing was first revealed in the late 1970s (Chaudhary et al., 2011). The green marketing concept was first discussed in a 1975 American Marketing Association (AMA) seminar on "ecological marketing" and took its place in the literature (Novela et al., 2018). Green marketing comprises of a wide range of commercial activities designed to meet the needs and desires of consumers and to reduce the negative effects on the natural environment (Tiwari et al., 2011). Furthermore, it was also described by the American Marketing Association (AMA) as "eco-marketing".

Furthermore, according to the American Marketing Association (AMA), the green marketing approach is the marketing of commodities focused primarily on environmental safety; it includes business activities consisting of packaging changes, production processes, and green ads (Yazdanifard \& Mercy, 2011). Besides, green marketing's main objectives were to reduce the environmental hazards caused by industrial and strengthen the customer's impression of corporate eco-centered image (Braimah, 2015). This kind of product or service can be environmentally friendly in it or manufactured and/or packaged in an environmentally friendly manner (Chaudhary et al., 2011). Green marketing can be described as a business operation that uses the environment as its main issue, utilizes human awareness of environmental issues, provides or offers goods or services with minimal environmental impact (Mantiaha, 2016).

H1: Green marketing has a positive influence on customer satisfaction.

\subsection{Green brand awareness}

Brand awareness is a condition in which customers recognize the brand of a product and are correctly connected to certain product categories (Mantiaha, 2016). Green brand awareness is characterized by the possibility of identifying and remembering the characteristics of a brand dedicated to preserving the environment (Mourad \& Ahmed, 
2012). Furthermore, green brand awareness is described as the customer's will and trust in a brand's product or service, where the brand has reputation, policies, and the ability to reduce the negative impact on the environment $(\mathrm{Ha}, 2004)$.

Environmentally friendly products and green brand awareness motivate customers that value the environment when considering their purchase decisions. It is the role of marketers to provide green product information, eco-friendly labeling by using content through green messages to educate consumers with their green brands (Tariq, 2014). Moreover, the green brand is a perception and association that the brand is committed to and has an interest in the environment in the minds of consumers (Praharjo, 2013). Green brand elements are divided into the green brand image, green satisfaction, and green trust (Chen, 2010: 308).

H2: Green brand awareness has a positive influence on customer satisfaction.

\subsection{Customer satisfaction}

Customer satisfaction is the satisfaction or dissatisfaction of the consumer as a reaction to the evaluation of the discrepancy between the initial perception before purchase (or another normal performance) and the actual performance of the product perceived after the product concerned has been used or consumed (Tjiptono \& Chandra, 2016). Customer satisfaction refers to the fulfillment of customer expectations concerning services and products, in particular quality. Satisfaction can only be obtained if perceived performance meets the needs of the customer or exceeds the expectations of the customer (Alabboodi, 2019).

Swenson \& Wells (1997) furthermore explained customer satisfaction as a process and as an outcome. As a process, it contributes to satisfaction by evaluating the perception and psychological processes. As an outcome, fulfilling the final condition arising from the experience of consumption. Related to the environmental sustainability, customers want to be associated with environmentally friendly companies and products, as a consequence, companies in their packaging, advertising, or manufacturing processes that communicate their 'environmentally friendly products' are getting satisfied customers (Yazdanifard \& Mercy, 2011).

H3: Green marketing and green brand awareness simultaneously have a positive influence on customer satisfaction.

\subsection{Framework}

This study uses a conceptual framework as defined below (Figure 1):

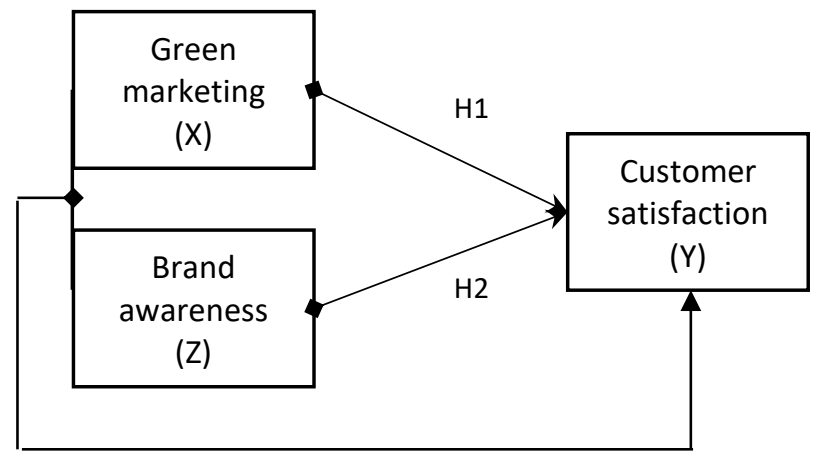

H3

Figure 1: Conceptual framework

Source: own construction 


\subsection{Previous studies}

A study conducted by Tariq (2014) regarding the impact of green brand awareness on green satisfaction in environmental-conscious consumers with the mediating role of consumer purchasing behavior towards green products. Green brand awareness has a positive influence on the green customer satisfaction of environmentally friendly products. The questionnaire was collected from 207 customers as the data source. Study findings also indicate that if businesses implement green marketing and advertising strategies then environmentally conscious consumers are willing to pay more to buy green products to satisfy their needs. A study by Sandra \& lyyapan (2017) examined different aspects of customer satisfaction and showed that marketing could influence the preference of consumers for greener products. The main hurdle to the purchasing of green products is whether the product can perform as expected. However, customers typically trust the performance of well-known brands, but instead green products that work well and do not make over-inflated green claims may successfully be marketed under well-known brands.

\section{Research methodology}

The study adopted a quantitative and empirical approach in the collection of research data by administering structured questionnaires in a survey. The questionnaire was developed based on the research objectives and the analysis of the relevant literature on green marketing, green brand awareness, and customer satisfaction. The population of this study is customers who consume Pristine $8+$ bottled mineral water products in the province of Riau, Indonesia. The sample size used consisted of 180 customers. In a quantitative study, the number of samples already met the minimum number of samples required (Sugiyono, 2016). Samples are obtained using the non-probability sampling method and using a purposive sampling technique. Customers who have used or bought pristine $8+$ bottled mineral water more than 2 times are the criteria applied, as it is assumed that the consumer has already purchased the product and is likely to use it again.

The study also sought to assess customer satisfaction with green marketing and awareness of the green brand, therefore the questionnaire provided the expression of views that attempted to quantify this. The data obtained is then measured by a Likert scale, and used Statistical Package for Social Sciences 22.0 (SPSS 22.0) for further statistical analysis. Results were interpreted and analyzed based on green marketing literature, green brand awareness, and other relevant empirical evidence, given due consideration to the study objective.

\subsection{The profile of the mineral water product}

Pristine $8+$ is a brand of bottled mineral water that has been treated by an ionization process. The feature of this product is the smaller structure of the water molecule that the body instantly absorbs. Additionally, Pristine $8+$ is rich in antioxidants and effectively counteracts the processes of oxidation that destroy the cells of the body. The number ' 8 ' represents the quantity of alkaline $\mathrm{pH}$ in one bottle of Pristine $8+$ that can also help to neutralize the acids of the body. Pristine $8+$ is made of pure and organic water from Mount Gede Pangrango's springs, Indonesia, and refined using advanced Japanese technology.

\subsection{Demographic of respondent}

The respondent's demographics were based on data from 180 respondents involved in completing the questionnaire (Table 1). Female respondents comprised $56.67 \%$ of the total number of respondents. The respondents' ages ranged from 21 to 25 (36.67\%), 26 to 35 $(23.89 \%), 16$ to $20(22.2 \%)$, and > 35 years (17.22\%). A large percentage of respondents 
as a student $(39.44 \%)$ followed by non-government employees (23.33\%), government employees (18.89\%), and others (18.33\%).

Table 1: Respondent demographics

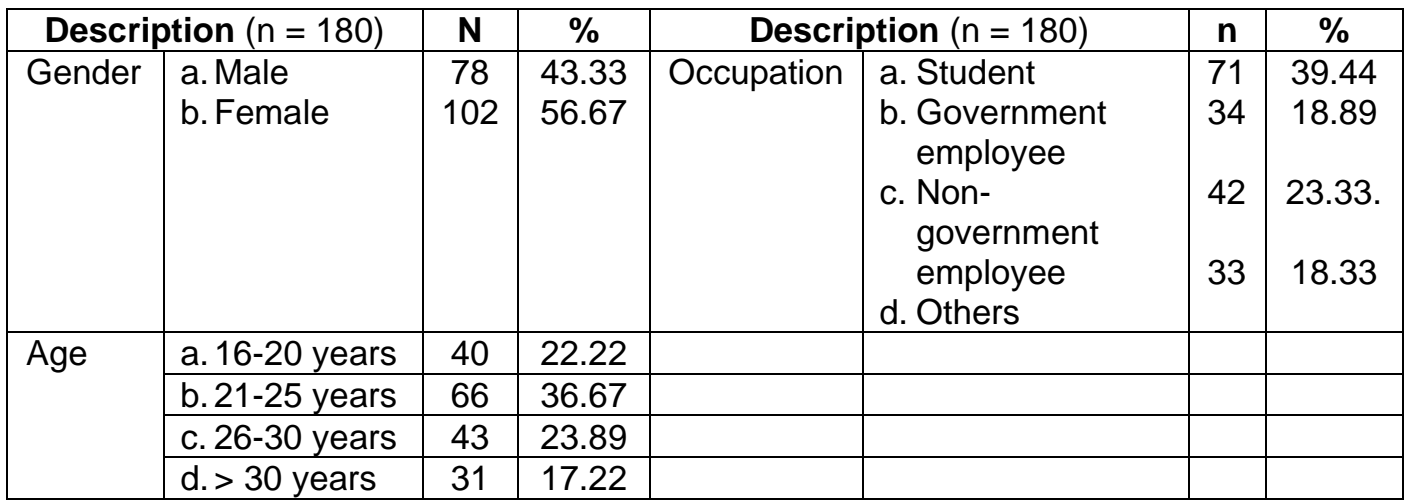

Source: Authors' computation

\section{Research Findings \& Discussion}

\subsection{Validity Test}

A validity test is a measurement of the degree of accuracy/appropriateness of the instruments used to measure what will be measured and a research questionnaire is of good quality if its validity and reliability have been proven. (Arifin, 2016). By comparing $r$-count with $r$-table, the validity check is performed. The element is said to be valid if $r$-count $>r$ table. The item of the questionnaire is said to be invalid if $r$-count $<r$ table (Sugiyono, 2016). The corrected item-total correlation value is referred to as the t-count value in the validity test (Table 2). The value of the product-moment $r$-table is derived from the value of statistics r-table based on the value of $\mathrm{df}$ (degree of freedom) used in this analysis, i.e. $\mathrm{df}=180-3=$ 177 , then the obtained value is based on $r$-table statistics with a $5 \%$ significance: $r$-table $=$ 0.148 . Based on a comparison of the values of $r$-count and $r$-table. It can then be concluded that all green marketing $(X)$, green brand awareness $(Z)$ and customer satisfaction $(Y)$ questionnaire statements are valid.

\subsection{Reliability Test}

Reliability test is defined as consistency when the test is tested many times the results are relatively the same, indicating that there are significant correlation results after the first test results are correlated with the next test (Arikunto, 2016). The reliability test is performed if the items of the questionnaire are declared valid and the statement items concluded on the questionnaire are reliable if the Cronbach alpha value obtained $>0.6$. If the alpha value of Cronbach $<0.6$ then the questionnaire items will be considered unreliable (Sugiyono, 2016). The calculation result of the Cronbach alpha value (Table 3 ) of 0.805 was obtained from the reliability test for variable $X$ with a questionnaire of 6 items, 0.820 for variable $Z$ with a questionnaire of 7 items and variable $Y$ used 3 items questionnaire of 0.665 . Since these three Cronbach alpha values $>0.6$, it is concluded that variable $X$ (green marketing, variable $\mathrm{Z}$ (green brand awareness) and variable $\mathrm{Y}$ (customer satisfaction) are declared reliable. 
Table 2: Validity test result

\begin{tabular}{|c|c|c|c|c|c|}
\hline Variable/s & $\begin{array}{l}\text { State } \\
\text { ments }\end{array}$ & $\begin{array}{l}\text { Corrected } \\
\text { Item-Total } \\
\text { Correlation } \\
\text { (r-count) }\end{array}$ & Variable/s & $\begin{array}{l}\text { State } \\
\text { ments }\end{array}$ & $\begin{array}{l}\text { Corrected } \\
\text { Item-Total } \\
\text { Correlation } \\
\text { (r-count) }\end{array}$ \\
\hline \multirow{6}{*}{$\begin{array}{l}\text { Green marketing } \\
(\mathrm{X})\end{array}$} & 1 & 0.512 (valid) & \multirow{2}{*}{$\begin{array}{c}\text { Customer } \\
\text { satisfaction } \\
(\mathrm{Y})\end{array}$} & 1 & 0.524 (valid) \\
\hline & 2 & 0.607 (valid) & & 2 & 0.469 (valid) \\
\hline & 3 & 0.579 (valid) & & 3 & 0.437 (valid) \\
\hline & 4 & 0.585 (valid) & & & \\
\hline & 5 & 0.607 (valid) & & & \\
\hline & 6 & 0.507 (valid) & & & \\
\hline \multirow{7}{*}{$\begin{array}{c}\text { Green brand } \\
\text { awareness }(Z)\end{array}$} & 1 & 0.616 (valid) & & & \\
\hline & 2 & 0.594 (valid) & & & \\
\hline & 3 & 0.611 (valid) & & & \\
\hline & 4 & 0.552 (valid) & & & \\
\hline & 5 & 0.600 (valid) & & & \\
\hline & 6 & 0.561 (valid) & & & \\
\hline & 7 & 0.453 (valid) & & & \\
\hline
\end{tabular}

Note: $r$-table $=0.148$; valid if $r$-count $>$ r-table

Source: Authors' computation

Table 3: Reliability test result

\begin{tabular}{|c|c|c|c|}
\hline $\mathbf{n}$ & Variable & Cronbach's Alpha & Result \\
\hline \multirow{3}{*}{180} & $\mathrm{X}$ & 0.805 & Reliable \\
\cline { 2 - 4 } & $\mathrm{Z}$ & 0.820 & Reliable \\
\cline { 2 - 4 } & $\mathrm{Y}$ & 0.665 & Reliable \\
\hline \multicolumn{4}{|l}{} \\
\hline
\end{tabular}

Source: Authors' computation

\subsection{Classic Assumption Test}

\subsubsection{Multicollinearity test}

The multicollinearity test aims to check whether the regression model has formed a correlation between independent variables (Sugiyono, 2016). In a good regression model, there should be no correlation between the independent variables (Ghozali, 2013). The tolerance value is $>0.10$ and the VIF value is < 10.00; multicollinearity does not occur. In compliance with the results of the multicollinearity testing output (table 4), the tolerance values of green marketing and green brand awareness with value 0.498 . It is stated that there are no symptoms of multicollinearity (the tolerance value of $0.498>0.10$ ). Besides, it is also supported by the VIF values obtained at $2.007<10.00$.

Table 4: Multicollinearity test result

\begin{tabular}{|l|l|c|c|}
\hline \multicolumn{2}{|c|}{} & Green Marketing & Green Brand Awareness \\
\hline Collinearity & Tolerance & 0.498 & 0.498 \\
\cline { 2 - 4 } Statistics & VIF & 2.007 & 2.007 \\
\hline
\end{tabular}

Source: Authors' computation 


\subsubsection{Heteroscedasticity test}

The purpose of the heteroscedasticity test is to examine whether there is a difference between the residuals from one result and another in the regression model. A good model of regression is homoscedasticity or there is no heteroscedasticity (Sugiyono, 2016). The basic decision for heteroscedasticity test: if the value of sig. (2-tailed) $>0.05$ then there is no heteroscedasticity problem. Conversely, if the significance value or sig. (2-tailed) $<0.05$ then there is a heteroscedasticity problem (Ghozali, 2013).

Table 5: Heteroscedasticity test result

\begin{tabular}{|l|l|c|}
\hline Spearman's rho & Unstandardized Residual \\
\hline Green Marketing & Sig. (2-tailed) & 0.093 \\
\hline Green Brand Awareness & Sig. (2-tailed) & 0.056 \\
\hline \multicolumn{2}{|c|}{$\mathrm{n}$} & 180 \\
\hline
\end{tabular}

Source: Authors' computation

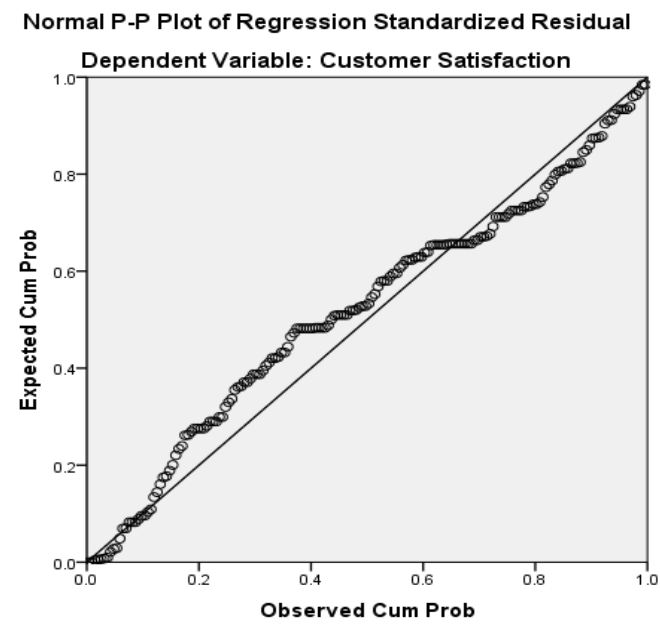

Figure 2. Normality test result

Source: Authors' computation

Based on the heteroscedasticity analysis (Table 5), the results obtained respectively for the green advertising of 0.93 and the green brand awareness of 0.56 . This is in line with the decision-making basis that states if sig. value (2-tailed) $>0.05$, then there is no heteroscedasticity problem.

\subsubsection{Normality test}

A normality test is necessary because it assumes that the residual value follows the normal distribution to evaluate certain variables. If this assumption is violated, the statistical test becomes invalid and it is not possible to use regression statistics (Arikunto, 2016). The basic decision for the normality test (Ghozali, 2013): If the data spread diagonally and follows the line, by diagonal or the histogram graph (Figure 2) shows a normal distribution, the regression model meets the assumption of normality. If the data spread widely away from the diagonal and/or does not follow the diagonal line direction or the histogram chart indicates no normal distribution, then the regression model does not satisfy the normality assumption. It can be seen from the test output (Figure 2), the data spread in the direction of the diagonal line. Therefore, it can be concluded that the data is normally distributed and then the hypothesis test can be performed. 


\subsection{Hypothesis test}

\subsection{1. t-test}

The t-test is performed to determine whether the independent variable $(X)$ partially influences the dependent variable $(\mathrm{Y})$ by comparing the t-counts of each independent variable with the $5 \%$ error rate of the table value $(\alpha=0.05)$. The independent variable provides a significant influence on the dependent variable if the value of the t-count $\geq t$-table. The t-test uses $\mathrm{df}=\mathrm{n}-\mathrm{k}-1$ degree of freedom where $\mathrm{n}=$ number of observations and $\mathrm{k}=$ number of variables (Sugiyono, 2016).

$\mathrm{t}$-table $=\mathrm{t}(\mathrm{\alpha} / 2 ; \mathrm{n}-\mathrm{k}-1)=\mathrm{t}(0.025 ; 177)=1.984$

Table 6: T-test result

\begin{tabular}{|l|l|c|c|}
\hline Model & t & Sig. \\
\hline \multirow{3}{*}{1} & (Constant) & 3.119 & 0.002 \\
\cline { 2 - 4 } & Green Marketing (X) & 1.483 & 0.140 \\
\cline { 2 - 4 } & Green Brand Awareness (Z) & 5.870 & 0.000 \\
\hline
\end{tabular}

Dependent Variable: Customer Satisfaction $(\mathrm{Y})$

Source: Authors' computation

The first $(\mathrm{H} 1)$ and second $(\mathrm{H} 2)$ hypothesis test results are as follows (Table 6): The Sig. value of the influence of $X$ on $Y$ is $0.140>0.05$ and the value of the $t$-count is $1.483<t$-table 1.984, then it can be inferred that $\mathrm{H} 1$ is rejected, implying that the variable $X$ does not influence the $Y$. The value of the influence of $Z$ on $Y$ is $0.000<0.05$ and the value of $t$-count $5.870>$ t-table 1.984 , it is concluded that $\mathrm{H} 2$ is accepted, indicating that variable $\mathrm{Z}$ has a positive influence on $\mathrm{Y}$.

\subsubsection{F-test}

F-test aims to determine the independent variables influence simultaneously on the dependent variable with a 5\% significance level (Sugiyono, 2016), with basic decisionmaking (Ghozali, 2013): F-count > F-table, the dependent variable is influenced simultaneously by the independent variables and If $F$-count $<F$ table, the dependent variable is not influenced simultaneously by the independent variables.

$\mathrm{F}$-table $=\mathrm{F}(\mathrm{k} ; \mathrm{n}-\mathrm{k})=\mathrm{F}(2 ; 180-2)=3.02$

The third hypothesis test uses F-test with the result as follows (Table 7):

Table 7: F-test result (Anova)

\begin{tabular}{|l|l|c|c|c|}
\hline Model & Mean Square & F & Sig. \\
\hline 1 & Regression & 138.057 & 49.148 & 0.000 \\
\cline { 2 - 3 } & Residual & 2.809 & & \\
\cline { 2 - 3 } & Total & 773.331 & & \\
\hline
\end{tabular}

a. Dependent Variable: Customer Satisfaction

b. Predictors: (Constant), Green Brand Awareness, Green Marketing

Source: Authors' computation

Based on the test output, the significance value for the influence of $X$ and $Z$ on $Y$ at simultaneously amounted to Sig. $0.000<0.05$ and the value of F-count $49.148>$ F-table 3.02 , and it was concluded that $\mathrm{H} 3$ is accepted; implying that variables $\mathrm{X}$ and $\mathrm{Z}$ were influenced simultaneously on variable $\mathrm{Y}$. 


\subsubsection{Coefficient of determination analysis}

The determination coefficient ( $R$ square) is used to measure and assessed the contribution level of the independent variables that influence the dependent variable simultaneously. The $\mathrm{F}$ test results that are significant are the criteria that must be met to interpret the $\mathrm{R}$ square value (Ghozali, 2013).

According to the test results in the model summary (Table 8), the R square value is 0.357 or $35.7 \%$. The number in the $R$ square implies that the variables of green marketing $(X)$ and green brand awareness $(\mathrm{Z})$ simultaneously influence the customer satisfaction variable $(\mathrm{Y})$ by $35.7 \%$. Whilst the rest $(100 \%-35.7 \%=64.3 \%)$ are influenced by other variables that are not examined

Table 8: Model summary

\begin{tabular}{|l|c|c|c|c|}
\hline Model & $\mathbf{R}$ & R Square & Adjusted R Square & Std. Error of the Estimate \\
\hline 1 & $.598^{\mathrm{a}}$ & .357 & .350 & 1.676 \\
\hline \multicolumn{3}{|l|}{ a. Predictors: (Constant), Green Brand Awareness (Z), Green Marketing (X) } \\
\hline
\end{tabular}

Source: Authors' computation

\section{Conclusion, Limitation, and Implication}

\subsection{Conclusion}

From the results of the analysis, conclusions drawn concerning the responses to the proposed hypotheses, i.e.:

Based on the first Hypothesis $(\mathrm{H} 1)$ test results, it was discovered that green marketing $(\mathrm{X})$ has no influence on customer satisfaction $(\mathrm{Y})$ of Pristine $8+$ brand bottled drinking water, identified with a significance value of variable X $0.140>0.05$ and t-count value $<\mathrm{t}$-table $(1.483<1.984)$. The results of the second hypothesis $(\mathrm{H} 2)$ test, supported the statement that green brand awareness $(\mathrm{Z})$ has a positive influence on customer satisfaction $(\mathrm{Y})$ of Pristine $8+$ bottled drinking water with a significance value $0.000<0.05$ and with the value of t-count $>$ t-table $(5870>1,984)$.

The third hypothesis $(\mathrm{H} 3)$ with test results supporting the hypothesis that green marketing $(X)$ and green brand awareness $(Z)$ simultaneously have a positive influence on customer satisfaction $(\mathrm{Y})$ of the Pristine $8+$ bottled water brand with test results sig value $0.000<0.05$ and F-count value $>$ F-table $(49.148>3.02)$. The value of $R$ square obtained by analyzing the determination coefficient ( $R$ square) is 0.357 . It means that the green marketing variable $(\mathrm{X})$ and green brand awareness variable ( $\mathrm{Z}$ ) simultaneously influence the customer satisfaction variable $(\mathrm{Y})$ by $35.7 \%$ and the rest is influenced by other variables that are not investigated.

\subsection{Limitation}

Although the study provides a certain perspective on how variables on the mineral water product influence customer satisfaction, it has some limitations. There is a limited number of respondents. A larger sample would have enhanced the results obtained. The empirical results could be influenced by these study design factors changing. Future studies should define and evaluate certain factors influencing customer satisfaction, such as the quality of green service/product or perceived values with the green image of the product brand. 


\subsection{Implication}

The results of this study, notably in the field of marketing management are expected to provide benefits for science growth. The outcomes of this study are expected to serve as a reference source for further studies. The results are also intended to be inputs as well as developing materials for the management of the company as a source of information and to facilitate appropriate decision making concerning the marketing strategy of bottled mineral water products.

\section{References}

Alabboodi, A. S. 2019. The effect of customer satisfaction on service quality: The case of Iraqi banks. International Journal of Applied Research, [e-journal] 5(1), pp.146-152. Available at: http://www.allresearchjournal.com/archives/2019/vol5issue1/PartC/4-12-66302.pdf [Accessed 20 April 2020]

Arifin, Z. 2016. Evaluasi Pembelajaran. Bandung: Remaja Rosda Karya.

Arikunto, S. 2016. Prosedur Penelitian: Suatu Pendekatan Praktik. Jakarta: Rineka Cipta. Braimah, M. 2015. Green brand awareness and customer purchase intention. Management Science Letters, [e-journal] 5, pp.895-902. https://doi.org/10.5267/j.msl.2015.8.007

Chaudhary, B., Tripathi, S., \& Monga, N. 2011. Green Marketing and CSR. International Journal of Research in Finance and Marketing, 1(6), pp.82-99. Available at: https://www.researchgate.net/publication/303923746 GREEN MARKETING AND CSR

[Accessed 15 February 2020]

Ghozali, I. 2013. Aplikasi Analisis Multivariate dengan Program SPSS. 7th ed. Semarang: Badan Penerbit Universitas Diponegoro.

Grant, J. 2008. Green marketing. Strategic Direction, [e-journal] 24(6), pp.25-27. https://doi.org/10.1108/02580540810868041

Ha, H. Y. 2004. Factors influencing consumer perceptions of brand trust online. Journal of Product \& Brand Management, [e-journal] 13(5), pp.329-342. https://doi.org/10.1108/10610420410554412

Mantiaha, G. F. 2016. The Influence of Green Marketing on Consumer Buying Behaviour. Jurnal EMBA, 4(6), pp.58-067. https://doi.org/10.35794/emba.v4i2.12494

Mourad, M., \& Ahmed, Y. S. E. 2012. Perception of the green brand in an emerging innovative market. European Journal of Innovation Management, [e-journal] 15(4), pp.514537. https://doi.org/10.1108/14601061211272402

Novela, S., Novita, \& Hansopaheluwakan, S. 2018. Analysis of green marketing mix effect on customer satisfaction using a $7 \mathrm{p}$ approach. Pertanika Journal of Social Sciences and Humanities, 26(T), pp.131-144. Available at: http://www.pertanika.upm.edu.my/Pertanika\%20PAPERS/JSSH\%20Vol.\%2026\%20(T)\%2 0Mar.\%202018/12\%20JSSH(T)-0670-2018-2ndProof.pdf [Accessed 20 April 2020]

Ottman, J. A., Stafford, E. R., \& Hartman, C. L. 2006. Avoiding green marketing myopia: Ways to improve consumer appeal for environmentally preferable products. Environment, [e-journal] 48(5), pp.22-36. https://doi.org/10.3200/ENVT.48.5.22-36

Parker, B., Segev, S., \& Pinto, J. 2010. What It Means to Go Green: Consumer Perceptions of Green Brands and Dimensions of "Greenness". American Academy of Advertising, pp.99111. Available at: https://www.tib.eu/en/search/id/BLCP\%3ACN076830329/What-It-Meansto-Go-Green-Consumer-Perceptions/ [Accessed 2 February 2020]

Praharjo, A. 2013. Pengaruh Green Advertising Terhadap Persepsi Tentang Green Brand Dan Keputusan Pembelian (Survei Pada Mahasiswa Fakultas IImu Administrasi Angkatan 2010/2011 Universitas Brawijaya Konsumen Air Minum Kemasan Merek Ades). Jurnal Administrasi Bisnis, $4(2), \quad$ pp.1-9. Available at: 
http://administrasibisnis.studentjournal.ub.ac.id/index.php/jab/article/view/181 [Accessed 25 March 2020]

Sandra, J. R., \& lyyapan, K. 2017. A Study on Green Marketing and Its Impact on Consumer Buying Behavior and Satisfaction Levels in Madurai. International Journal of Innovative Research in Management Studies, 2(7), pp.1-4. Available at: http://www.ijirms.com/downloads/10082017080817-80.pdf [Accessed 25 March 2020] Sugiyono. 2016. Metode Penelitian Kuantitatif, Kualitatif dan R\&D. Bandung: PT. Alfabeta. Swenson, M. R., \& Wells, W. D. 1997. Social Marketing: Theoretical and Practical Perspectives. 1st ed. New York: Psychology Press.

Tariq, M. Z. 2014. Impact of Green Advertisement and Green Brand Awareness on Green Satisfaction with the Mediating Effect of Buying Behavior. Journal of Managerial Sciences, $8(2)$, pp.274-289. Available at: https://www.researchgate.net/publication/301780191 Impact of Green Advertisement an d Green Brand Awareness on Green Satisfaction with Mediating Effect of Buying B ehavior [Accessed 13 March 2020]

Tiwari, S., Tripathi, D. M., Srivastava, U., \& Yadav, P. K. 2011. Green Marketing - Emerging Dimensions. Journal of Business Excellence, 2(1), pp.18-23. Available at: https://bioinfopublication.org/files/articles/2 12 JBE.pdf [Accessed 27 March 2020]

Tjiptono, F., \& Chandra, G. 2016. Service, Quality \& satisfaction. Yogyakarta: Penerbit Andi. Yan, Y. K., \& Yazdanifard, R. 2014. The Concept of Green Marketing and Green Product Development on Consumer Buying Approach. Global Journal of Commerce \& Management Perspective, $3(2)$, pp.33-38. Available at: https://www.researchgate.net/publication/268747494 THE CONCEPT OF GREEN MAR KETING AND GREEN PRODUCT DEVELOPMENT ON CONSUMER BUYING APP ROACH [Accessed 11 April 2020]

Yazdanifard, R., \& Mercy, I. E. 2011. The impact of Green Marketing on Customer satisfaction and Environmental safety. Journal of Computer Communication and Management, $5, \quad$ pp.637-641. Available at: https://www.researchgate.net/publication/268502673 The impact of Green Marketing o n Customer satisfaction and Environmental safety [Accessed 27 March 2020]

\section{Bio-note}

Alum Kusumah, DR, Faculty of Economics and Business, Universitas Muhammadiyah Riau, Indonesia. Research interest: International Business Management, Human Resources Management, Operational Management, Marketing, and Organizational Behaviour. Cheng-Wen Lee, DR, is a Professor in the Department of International Business, College of Business, Chung Yuan Christian University, Taiwan. Research interests: International Business Management, International Marketing, International Marketing Management, and Global Logistics Management. 


\section{Appendix 1.}

\section{Questionnaire regarding GREEN MARKETING AND GREEN BRAND AWARENESS INFLUENCE CUSTOMER SATISFACTION}
* Please tick one box at a time for every question.
* Please answer all questions in the survey

\begin{tabular}{|l|l|l|}
\hline \multicolumn{1}{|c|}{ Gender } & \multicolumn{1}{|c|}{ Age } & \multicolumn{1}{c|}{ Occupation } \\
\hline$\square$ Male & $\square 16-20$ years & $\square$ Student \\
$\square$ Female & $\square 21-25$ years & $\square$ Government employee \\
& $\square 26-30$ years & $\square$ Non-government employee \\
& $\square>30$ years & $\square$ Others \\
\hline
\end{tabular}

\section{Evaluation Scale:}

5 - Strongly agree, 4 - Agree, 3 - Neutral, 2 - Disagree, 1 - Strongly disagree

\begin{tabular}{|c|l|l|l|l|l|l|}
\hline Section 1: Green Marketing \\
\hline 1 & $\begin{array}{l}\text { I use Pristine 8+ bottled mineral water because of } \\
\text { advertising in the mass media as an eco-friendly product. }\end{array}$ & 5 & 4 & 3 & 2 & 1 \\
\hline 2 & $\begin{array}{l}\text { Product information, labeling, and packaging design that } \\
\text { includes information on Pristine 8+ bottled mineral water } \\
\text { truly represents an environmentally friendly product. }\end{array}$ & 5 & 4 & 3 & 2 & 1 \\
\hline 3 & $\begin{array}{l}\text { I feel that the Pristine 8 + bottled mineral water product } \\
\text { advertising activity is an honest campaign. }\end{array}$ & 5 & 4 & 2 & 1 \\
\hline 4 & $\begin{array}{l}\text { The Pristine 8+ bottled mineral water product is relatively } \\
\text { affordable and easy to find. }\end{array}$ & 5 & 4 & 3 & 2 & 1 \\
\hline 5 & $\begin{array}{l}\text { The Pristine 8 + bottled mineral water product collaborates } \\
\text { in its promotional activities with communities that care about } \\
\text { environmental sustainability. }\end{array}$ & 5 & 4 & 3 & 2 & 1 \\
\hline 6 & $\begin{array}{l}\text { The eco-friendly information on Pristine 8+ bottled mineral } \\
\text { water products in promotional and advertising activities is } \\
\text { easy to understand. }\end{array}$ & 5 & 4 & 3 & 2 & 1 \\
\hline Section 2: Green Brand Awareness & $\begin{array}{l}\text { I have an awareness of the importance of using } \\
\text { environmentally friendly products to preserve nature. }\end{array}$ & 5 & 4 & 3 & 2 & 1 \\
\hline 2 & $\begin{array}{l}\text { If I see an environmental label on a product or brand, I will } \\
\text { highly consider using it rather than non-label. }\end{array}$ & 5 & 4 & 3 & 2 & 1 \\
\hline $\begin{array}{l}\text { By consuming Pristine 8 + bottled mineral water product I } \\
\text { believe that it is not only eco-friendly but also beneficial for } \\
\text { our health. }\end{array}$ & 5 & 4 & 3 & 2 & 1 \\
\hline
\end{tabular}




\begin{tabular}{|c|l|l|l|l|l|l|}
\hline 4 & $\begin{array}{l}\text { Producers of Pristine 8 + bottled mineral water products } \\
\text { have a good record of accomplishment in environmental } \\
\text { preservation. }\end{array}$ & 5 & 4 & 3 & 2 & 1 \\
\hline 5 & $\begin{array}{l}\text { I am willing to pay more for drinking Pristine 8 + bottled } \\
\text { mineral water products since it is an eco-friendly product. }\end{array}$ & 5 & 4 & 3 & 2 & 1 \\
\hline 6 & $\begin{array}{l}\text { By using Pristine 8+ bottled mineral water products, I believe } \\
\text { that I have contributed to the effort to preserve the } \\
\text { environment. }\end{array}$ & 5 & 4 & 3 & 2 & 1 \\
\hline 7 & $\begin{array}{l}\text { I recognize the producers of Pristine 8 + bottled mineral } \\
\text { water products educate consumers about sustainability in } \\
\text { the environment. }\end{array}$ & 5 & 4 & 3 & 2 & 1 \\
\hline Section 3: Customer Satisfaction & $\begin{array}{l}\text { I am satisfied to use the Pristine 8+ bottled mineral water } \\
\text { product. }\end{array}$ & 5 & 4 & 3 & 2 & 1 \\
\hline 2 & $\begin{array}{l}\text { I will recommend using Pristine 8 + bottled mineral water } \\
\text { products to friends and colleagues. }\end{array}$ & 5 & 4 & 3 & 2 & 1 \\
\hline 3 & $\begin{array}{l}\text { Pristine 8+ bottled mineral water product is my best choice } \\
\text { when it comes to drinking mineral water products. }\end{array}$ & 5 & 4 & 3 & 2 & 1 \\
\hline
\end{tabular}

